\title{
BREAST CANCER AND FAMILY HISTORY FOR BREAST CANCER IN PATIENTS WITH DIFFERENTIATED THYROID CARCINOMA
}

\section{DİFERANSIYYE TİROIDD KANSERLİ HASTALARDA MEME KANSERİ VE MEME KANSERİ İÇİN AÍLE HİKAYESİ}

Şafak AKIN ${ }^{1}$, Erkam SENCAR ${ }^{2}$, Davut SAKIZ², Melia KARAKÖSE ${ }^{3}$, Özgür ÖZÇELİK², Mahmut APAYDIN ${ }^{2}$, İlknur ÜNSAL ${ }^{2}$, Bekir UÇAN², Mustafa ÖZBEK ${ }^{2}$, Erman ÇAKAL ${ }^{2}$

${ }^{1}$ Private Memorial Ankara Hospital, Endocrinology and Metabolism, Ankara, Turkey.

${ }^{2}$ Dışkapı Yıldırım Beyazıt Training and Research Hospital, Clinic of Endocrinology and Metabolism, Ankara, Turkey.

${ }^{3}$ Necmettin Erbakan University, Meram Medical School, Department of Endocrinology and Metabolism, Konya, Turkey.

Ankara Eğt. Arş. Hast. Derg. (Med. J. Ankara Tr. Res. Hosp.) Cilt / Volume: 52 Sayı / Number: 1 Yıl / Year: 2019 ISSN:1304-6187

Sayfa/Page : 79-82

Geliş Tarihi / Submitted : Ocak 2019 /January 2019

Kabul Tarihi / Accepted : Mart 2019 / March 2019

\begin{abstract}
INTRODUCTION: The risk for breast cancer in patients with thyroid cancer has been investigated in previous studies, and has been found to be increased. In this study, we present a retrospective analysis of patients with differentiated thyroid carcinoma in respect to breast cancer and family history of breast cancer.
\end{abstract}

METHODS: We conducted a retrospective study involving 455 patients who were diagnosed as having differentiated thyroid carcinoma between January 2009 and March 2016.

RESULTS: The majority of the patients were female (403, $88.6 \%)$. The mean age at diagnosis was $45.5 \pm 12.8$ years (range, $10-81$ years). We detected that $0.7 \%$ of patients with thyroid cancer had breast cancer and $13.4 \%$ of patients had a family history of breast cancer within 3 generations of the proband. There were no significant differences between family history of breast cancer and sex, age at diagnosis, pathologic types, and radioiodine therapy.

CONCLUSION: In the literature, there are many clinical, epidemiologic, and experimental studies that show an association between thyroid cancer and breast cancer. Our study is the first report to show history of breast cancer and family history of breast cancer as $0.7 \%$ and $13.4 \%$ in this particular group of Turkish patients with differentiated thyroid cancer.

Key words: Breast cancer, thyroid cancer, family history for breast cancer.
ÖZET

AMAÇ: Tiroid kanserli hastalarda meme kanseri riskini araştıran ve artıș olduğunu gösteren çalışmalar mevcuttur. Bu çalışmada, diferansiye tiroid kanserli vakalarda meme kanseri varlığ 1 ve ailede meme kanseri hikayesinin varlığı retrospektif olarak araştırıldı.

YÖNTEM: Ocak 2009 - Mart 2016 tarihleri arasında diferansiye tiroid kanseri tanısı alan 455 hastanın retrospektif olarak değerlendirilmesi yapıldı.

BULGULAR: Hastaların çoğunluğu kadındı (403, \%88.6). Tanı sirasındaki ortalama yas $45.5 \pm 12.8$ yıl (dağılım $10-81$ yıl) idi. Tiroid kanserli hastaların \%0.7'sinin meme kanseri oldugunu ve \%13.4 'ünde ailede geriye doğru 3 kuşakta meme kanseri öyküsü olduğunu tespit ettik. Ailede meme kanseri öyküsü ile cinsiyet, tanı yaşı, patolojik alt tipler ve radyoiyot tedavisi arasında anlamlı fark saptanmadi.

SONUC: Literatürde tiroid kanseri ile meme kanseri arasında ilişki olduğunu gösteren bir çok klinik, epidemiyolojik ve deneysel çalışma bulunmaktadır. Çalışmamız, diferansiye tiroid kanserli Türk hasta grubunda meme kanseri öyküsü ve ailede meme kanseri öyküsünü sirayla \%0.7 ve\%13.4 olarak gösteren ilk rapordur.

Anahtar Kelimeler: Meme kanseri, tiroid kanseri, ailede meme kanseri hikayesi

Sorumlu Yazar / Corresponding Author:

Şafak AKIN

Private Memorial Hospital, Endocrinology and Metabolism, Ankara, Turkey

Gsm: +90 5322206940 E-posta: safakcavus@gmail.com 


\section{INTRODUCTION}

Differentiated thyroid carcinoma is the most common endocrine malignancy and its incidence is increasing worldwide $(1,2)$. Differentiated papillary and follicular histologies account for approximately $90 \%$ of thyroid carcinoma cases and have 5-year and 10-year survival rates of 95-97 \% (3). It is well known that thyroid carcinoma is sex biased and it mostly affects the female population. In the literature, breast cancer is the most frequently diagnosed malignancy in women (4). The association between the incidence of thyroid cancer and breast cancer has been reported previously. The risk for breast cancer in patients with thyroid cancer has been investigated in many studies (5-8), and has been found increased. The possible causes for the increased risk of breast cancer in patients with thyroid cancer remain unclear. The cause may include various factors such as exposure to ionizing radiation from radioiodine (RAI) therapy, genetic predisposition, and hormonal or environmental factors (9-12). In this study, we present a retrospective analysis of 455 patients with differentiated thyroid carcinoma in respect to breast cancer and family history of breast cancer.

\section{MATERIALS and METHODS}

\section{Study Population}

We conducted a retrospective study involving 455 patients who were diagnosed as having differentiated thyroid carcinoma between January 2009 and March 2016. No patients had a history of thyroid or neck surgery for non-thyroidal cancer or neck irradition. Medical records, radiologic and pathologic reports were analyzed. Papillary thyroid carcinomas measuring 10 $\mathrm{mm}$ or less in diameter were classified as papillary thyroid microcarcinoma (PTMC). Data points collected included: age at diagnosis ( $\geq 45$ vs. $<45$ years), sex, family history of both breast and thyroid cancer, preoperative clinical suspicion of cancer in ultrasonography (USG) findings, pathologic types, tumor size, multifocality, chronic lymphocytic thyroiditis, extrathyroidal extension, central or lateral lymph nodes with metastatic carcinoma, distant metastasis, type of surgery (thyroidectomy with or without central lymph node dissection), RAI treatment, thyroid-stimulating hormone (TSH), thyroglobulin (TG), thyroid globulin antibody (TGAb), and thyroid peroxidase antibody (TPOAb). Tumor size was defined as the largest dimension. Multifocality was defined as greater than 1 focus of tumor within the thyroid.

\section{Statistical Analysis}

Statistical analyses were performed using SPSS version 18.0 (SPSS Inc., Chicago, IL, USA). Data with normal distribution are expressed as mean \pm SD and were compared using t-test. Categorical variables are expressed as percentage and were compared using the Chi-square test or Fisher's exact test, as appropriate. Non-parametric variables were analyzed using the Mann-Whitney U test. In the statistical analyses, $\mathrm{p}<0.05$ value was considered significant.

\section{RESULTS}

The study population included 455 patients, the majority of whom were female $(403,88.6 \%)$. The mean age at diagnosis was $45.5 \pm 12.8$ years (range, 10 - 81 years) and 240 patients $(52.7 \%)$ were aged $\geq 45$ years. Table 1 lists the demographic characteristics of the study population.

We detected that $0.7 \%$ patients with thyroid cancer had breast cancer, and $13.4 \%$ patients had a family history of breast cancer within 3 generations of the proband. In three patients who had both thyroid and breast cancer, two had primary breast cancer first followed by thyroid cancer, and one had primary thyroid cancer first followed by breast cancer. In addition, among these three patients, two had a family history of breast cancer, one had an aunt with breast cancer, and the other had a sister with breast cancer. There were no significant differences between family history of breast cancer and sex, age at diagnosis, pathologic types, and RAI therapy.

\section{Table 1 Patient Characteristics}

\begin{tabular}{|c|c|}
\hline Variable & $\mathrm{N}=455$ \\
\hline $\begin{array}{l}\text { Sex }(n, \%) \\
\text { Female } \\
\text { Male }\end{array}$ & $\begin{array}{c}403,88.6 \\
52,11.4\end{array}$ \\
\hline Age at diagnosis $($ mean \pm SD $)$ & $45.5 \pm 12.8$ \\
\hline $\begin{array}{l}\text { Age }(\mathrm{n}, \%) \\
<45 \text { years } \\
\geq 45 \text { years }\end{array}$ & $\begin{array}{l}215,47.3 \\
240,52.7\end{array}$ \\
\hline Follow-up time (months) & $1-264(24)$ \\
\hline
\end{tabular}

$\begin{array}{lc}\text { Papillary carcinoma (PTC) } & 191,42.0 \\ \text { Papillary microcarcinoma (PTMC) } & 229,50.3 \\ \text { Follicular carcinoma (FC) } & 15,3.3 \\ \text { WDTN-UMP } & 6,1.3 \\ \text { PTC and FC } & 5,1.1 \\ \text { PTMC and WDTN-UMP } & 5,1.1 \\ \text { PTMC and FC } & 3,0.7 \\ \text { PTC and WDTN-UMP } & 1,0.2\end{array}$

Second primary malignancy $(\mathrm{n}, \%)$

\begin{tabular}{l|l} 
Breast cancer & $3,0.7$ \\
Renal cell cancer & $2,0.4$ \\
Colon cancer & $2,0.4$ \\
Endometrial cancer & $1,0.2$ \\
Parathyroid cancer & $1,0.2$
\end{tabular}

Family history of breast cancer (n, \%) $\quad 61,13.4$

Family history of thyroid cancer (n, \%) $\quad 41,9.0$

RAI therapy (n, \%)
Absent
$119,26.2$
Present
$336,73.8$

${ }^{1}$ WDTN-UMP: Well-differentiated thyroid neoplasms of uncertain malignant potential.

Among 455 patients with differentiated thyroid cancer, we evaluated 186 patient's long-term follow-up data (Table 2). 
Table 2 Clinicopathologic Characteristics and Long-term Follow-up Results of 186 Patients with Differentiated Thyroid Cancer

\begin{tabular}{|c|c|}
\hline Variable & $N=186$ \\
\hline $\begin{array}{l}\text { Sex }(\mathrm{n}, \%) \\
\text { Female } \\
\text { Male }\end{array}$ & $\begin{array}{l}160,86.0 \\
26,14.0\end{array}$ \\
\hline Age at diagnosis (mean $\pm \mathrm{SD})$ & $46.4 \pm 13.2$ \\
\hline $\begin{array}{l}\text { Age }(\mathrm{n}, \%) \\
<45 \text { years } \\
\geq 45 \text { years }\end{array}$ & $\begin{array}{c}86,46.2 \\
100,53.8\end{array}$ \\
\hline Body mass index $\left(\mathrm{kg} / \mathrm{m}^{2}\right)$ & $28.9 \pm 5.1$ \\
\hline Diabetes mellitus (n, \%) & $37,19.9$ \\
\hline $\begin{array}{l}\text { Clinical suspicion on preoperative USG } \\
(\%)\end{array}$ & 37.1 \\
\hline $\begin{array}{l}\text { Second primary malignancy }(\mathrm{n}, \%) \\
\text { Breast cancer } \\
\text { Renal cell cancer } \\
\text { Colon cancer }\end{array}$ & $\begin{array}{l}1,0.5 \\
2,0.5 \\
2,0.5\end{array}$ \\
\hline Family history of breast cancer (n, \%) & $17,9.1$ \\
\hline Family history of thyroid cancer (n, \%) & $19,10.2$ \\
\hline Preoperative TSH level $(\mu \mathrm{U} / \mathrm{mL})$ & $0.01-27.3(1.6)$ \\
\hline \multicolumn{2}{|l|}{ Pathologic types (n, \%) } \\
\hline $\begin{array}{l}\text { Papillary carcinoma (PTC) } \\
\text { Papillary microcarcinoma (PTMC) } \\
\text { PTMC and FC } \\
\text { WDTN-UMP } \\
\text { PTC and FC } \\
\text { PTC and WDTN-UMP }\end{array}$ & $\begin{array}{l}74,39.8 \\
98,52.7 \\
3,1.6 \\
1,0.5 \\
1,0.5 \\
1,0.5\end{array}$ \\
\hline $\begin{array}{l}\text { PTC variant (\%) } \\
\text { Follicular } \\
\text { Classic }\end{array}$ & $\begin{array}{l}19.4 \\
18.8\end{array}$ \\
\hline Tumor size $(\mathrm{cm})$ & $0.1-6.8(0.9)$ \\
\hline Presence of multifocality (n, \%) & 44.1 \\
\hline $\begin{array}{l}\text { Presence of extrathyroidal extension } \\
(\mathrm{n}, \%)\end{array}$ & 4.8 \\
\hline $\begin{array}{l}\text { Presence of chronic lymphocytic } \\
\text { thyroiditis (\%) }\end{array}$ & 36.6 \\
\hline \multicolumn{2}{|l|}{ Surgical treatment (n, \%) } \\
\hline $\begin{array}{l}\text { Total or near-total thyroidectomy } \\
\text { Lobectomy } \\
\text { Central lymph node dissection } \\
\text { Lateral lymph node dissection }\end{array}$ & $\begin{array}{l}185,99.5 \\
1,0.5 \\
54,29.0 \\
7,3.8\end{array}$ \\
\hline $\begin{array}{l}\text { RAI therapy (n, \%) } \\
\text { Absent } \\
\text { Present }\end{array}$ & $\begin{array}{c}55,29.6 \\
131,70.4\end{array}$ \\
\hline $\begin{array}{l}\text { Postoperative permanent } \\
\text { hypoparathyroidism (n, \%) }\end{array}$ & $20,10.8$ \\
\hline Distant metastasis (n, \%) & $1,0.5$ \\
\hline Lymph node metastasis (n, \%) & $20,10.8$ \\
\hline Follow-up time (months) & $1-264(21.5)$ \\
\hline
\end{tabular}

Of all 186 patients, 61 (32.8\%) had lymph nodes removed, $15(24.5 \%)$ had central lymph node metastasis only, and 5 (8.2 \%) had both central and lateral lymph node metastasis. According to the clinicopathologic characteristics and long-term follow-up period there was no differences among patients with and without family history of breast cancer in either the univariate or multivariate logistic regression analyses.

\section{DISCUSSION}

In this study, $0.7 \%$ of the patients with thyroid cancer were diagnosed as having second primary breast cancer. We also found that $13.4 \%$ of the patients with thyroid cancer had a family history of breast cancer. As reported, there are many clinical, epidemiological, and experimental studies that show an association between thyroid cancer and breast cancer (7, 13-15). Moreover, an increased risk of thyroid cancer was reported in individuals with history of breast cancer (15-17). An et al. (7) reported that $4.3 \%$ of patients with thyroid cancer and $2.6 \%$ of those with breast cancer were diagnosed as having second primary or concomitant breast cancer and thyroid cancer, respectively. Another study by Zhang et al. (15) showed that the overall risk of occurrence of a second primary thyroid cancer or breast cancer was highly elevated in patients with breast cancer or thyroid cancer.

Several recent studies concluded that thyroid cancer and breast cancer are closely related; however, the exact mechanisms that bind thyroid cancer and breast cancer have not yet been clearly identified. Nielsen et al.(18) reviewed thyroid cancer and breast cancer survivors received an increased surveillance in the form of clinical examinations and imaging, and it may be that the increase in surveillance is responsible for the higher rates of thyroid cancer or breast cancer detection. Previous studies also suggested a role for hormone receptors in the molecular pathogenesis of thyroid cancer. Estrogen, progesterone, and androgen receptors have been shown to be expressed in both normal and malignant thyroid tissue (19). Additionally, estrogen receptor levels are significantly higher in thyroid cancer compared with normal thyroid tissue (20). In our study, we did not the evaluate the hormone receptor situation in our three patients with thyroid and breast cancer and 67 family members with breast cancer.

In the literature, many previous studies demonstrated an increased prevalence of autoimmune thyroid disease in patients with breast cancer (21-23). Our study also investigated the presence of lymphocytic thyroiditis in patients with thyroid cancer. We were unable to detect a significant association between lymphocytic thyroiditis and family history for breast cancer using both univariate and multivariate analyses. Additionally, we observed that there was no significant association between the prevalence of anti-TPOAb and family history of breast cancer in patients with thyroid cancer. 
Obesity has been associated with increased incidence of thyroid and breast cancer $(18,24)$. In our study, the majority of patients were overweight with a mean body mass index (BMI) of $28.9 \pm 5.1 \mathrm{~kg} / \mathrm{m}^{2}$. We were unable to detect a significant difference between BMI and family history of breast cancer.

Some treatment characteristics affect the risk profiles for developing subsequent primary breast or thyroid cancer such as RAI therapy. An increased risk of second primary malignancy after RAI treatment has been reported (25). Lin et al. (26) showed that patients with thyroid cancer treated with RAI had a significantly increased risk of breast cancer compared with controls. In our study, 73.8 $\%$ patients were treated with RAI and we were unable to detect a correlation between second primary breast cancer and RAI treatment.

This study has limitations. Evidence derived from a retrospective cohort study is generally lower in statistical quality because of many biases and the necessary adjustments for confounding factors.

\section{CONCLUSION}

Our study is the first report to show the history of breast cancer and family history of breast cancer as $0.7 \%$ and $13.4 \%$ in this particular group of Turkish patients with differentiated thyroid cancer. We still need further studies to identify a subgroup of patients with higher risk of breast cancer in patients with thyroid cancer.

\section{REFERENCES}

1.)Hayat MJ, Howlader N, Reichman ME, Edwards BK. Cancer statistics, trends, and multiple primary cancer analyses from the Surveillance, Epidemiology, and End Results (SEER) Program. The oncologist. 2007; 12:20-37.

2.)Chen AY, Jemal A, Ward EM. Increasing incidence of differentiated thyroid cancer in the United States, 1988-2005. Cancer. 2009; 115:3801-7.

3.) Garner CN, Ganetzky R, Brainard J, et al. Increased prevalence of breast cancer among patients with thyroid and parathyroid disease. Surgery. 2007; 142:806-13; discussion 13 e1-3.

4.)Joseph KR, Edirimanne S, Eslick GD. The association between breast cancer and thyroid cancer: a meta-analysis. Breast cancer research and treatment. 2015; 152:173-81.

5.) Vassilopoulou-Sellin R, Palmer L, Taylor S, Cooksley CS. Incidence of breast carcinoma in women with thyroid carcinoma. Cancer. 1999; 85:696-705.

6.) Kuo JH, Chabot JA, Lee JA. Breast cancer in thyroid cancer survivors: An analysis of the Surveillance, Epidemiology, and End Results-9 database. Surgery. 2016; 159:23-9.

7.)An JH, Hwangbo Y, Ahn HY, et al. A Possible Association Between Thyroid Cancer and Breast Cancer. Thyroid : official journal of the American Thyroid Association. 2015; 25:1330-8.

8.)Subramanian S, Goldstein DP, Parlea L, et al. Second primary malignancy risk in thyroid cancer survivors: a systematic review and meta-analysis. Thyroid : official journal of the American Thyroid Association. 2007; 17:1277-88.

9.) Goldman MB, Maloof F, Monson RR, Aschengrau A, Cooper DS, Ridgway EC. Radioactive iodine therapy and breast cancer. A follow-up study of hyperthyroid women. American journal of epidemiology. 1988; 127:969-80.

10.)Ron E, Curtis R, Hoffman DA, Flannery JT. Multiple primary breast and thyroid cancer. British journal of cancer. 1984; 49:87-92. 11.)Kumar A, Klinge CM, Goldstein RE. Estradiol-induced proliferation of papillary and follicular thyroid cancer cells is mediated by estrogen receptors alpha and beta. International journal of oncology. 2010; 36:1067-80.

12.)Vivacqua A, Bonofiglio D, Albanito L, et al. 17beta-estradiol, genistein, and 4-hydroxytamoxifen induce the proliferation of thyroid cancer cells through the g protein-coupled receptor GPR30. Molecular pharmacology. 2006; 70:1414-23.

13.)Brown AP, Chen J, Hitchcock YJ, Szabo A, Shrieve DC, Tward JD. The risk of second primary malignancies up to three decades after the treatment of differentiated thyroid cancer. The Journal of clinical endocrinology and metabolism. 2008; 93:504-15.

14.)Consorti F, Di Tanna G, Milazzo F, Antonaci A. Nulliparity enhances the risk of second primary malignancy of the breast in a cohort of women treated for thyroid cancer. World journal of surgical oncology. 2011; 9:88.

15.)Zhang L, Wu Y, Liu F, Fu L, Tong Z. Characteristics and survival of patients with metachronous or synchronous double primary malignancies: breast and thyroid cancer. Oncotarget. 2016.

16.)Tanaka H, Tsukuma H, Koyama H, Kinoshita $Y$, Kinoshita N, Oshima A. Second primary cancers following breast cancer in the Japanese female population. Japanese journal of cancer research : Gann. 2001; 92:1-8.

17.)Evans HS, Lewis CM, Robinson D, Bell CM, Moller H, Hodgson SV. Incidence of multiple primary cancers in a cohort of women diagnosed with breast cancer in southeast England. British journal of cancer. 2001; 84:435-40.

18.) Nielsen SM, White MG, Hong S, et al. The Breast-Thyroid Cancer Link: A Systematic Review and Meta-analysis. Cancer epidemiology, biomarkers \& prevention : a publication of the American Association for Cancer Research, cosponsored by the American Society of Preventive Oncology. 2016; 25:231-8.

19.)Yane K, Kitahori Y, Konishi N, et al. Expression of the estrogen receptor in human thyroid neoplasms. Cancer letters. 1994; 84:59-66. 20.)Manole D, Schildknecht B, Gosnell B, Adams E, Derwahl M. Estrogen promotes growth of human thyroid tumor cells by different molecular mechanisms. The Journal of clinical endocrinology and metabolism. 2001; 86:1072-7.

21.)Gogas J, Kouskos E, Tseleni-Balafouta S, et al. Autoimmune thyroid disease in women with breast carcinoma. European journal of surgical oncology : the journal of the European Society of Surgical Oncology and the British Association of Surgical Oncology. 2001; 27:626-30.

22.)Hardefeldt PJ, Eslick GD, Edirimanne S. Benign thyroid disease is associated with breast cancer: a meta-analysis. Breast cancer research and treatment. 2012; 133:1169-77.

23.)Smyth PP. The thyroid, iodine and breast cancer. Breast cancer research : BCR. 2003; 5:235-8.

24.)Paes JE, Hua K, Nagy R, Kloos RT, Jarjoura D, Ringel MD. The relationship between body mass index and thyroid cancer pathology features and outcomes: a clinicopathological cohort study. The Journal of clinical endocrinology and metabolism. 2010; 95:4244-50. 25.)Fallahi $B$, Adabi $K$, Majidi $M$, et al. Incidence of second primary malignancies during a long-term surveillance of patients with differentiated thyroid carcinoma in relation to radioiodine treatment. Clinical nuclear medicine. 2011; 36:277-82.

26.)Lin CY, Lin CL, Huang WS, Kao CH. Risk of Breast Cancer in Patients with Thyroid Cancer Receiving or Not Receiving 131I Treatment: A Nationwide Population-Based Cohort Study. Journal of nuclear medicine : official publication, Society of Nuclear Medicine. 2016; 57:685-90. 